\title{
A TEXT ANALYSIS ON PRESIDENT JOKO WIDODO'S SPEECH AT APEC CEO SUMMIT ASIAN PACIFIC
}

\author{
Ahmad Madkur \\ Institut Agama Islam Negeri Metro, Lampung \\ Email: ahmadmadzkur@metrouniv.ac.id
}

\begin{abstract}
According to Van Dijk, there are three dimensions of discourse analysis, namely text, social cognition and social context. This study was focused on the first dimension, text. Joko Widodo's first presidential English speech on economic issues in front of international audience in CEO Summit in Beijing was one of speeches a lot of people talk about. Some like while some others dislike. This study was intended to analyze the transcript of the speech. This text analysis was based on Van Dijk's design in which the unit elements of the analysis are divided into three parts: macro-structure, suprastructure and microstructure. The result of the analysis revealed that in macrostructure element, several sentences in the presidential speech were less coherent in term of stating theme. Then, in suprastructure, the scheme of the speech consisted of opening, content and closing. Finally, in the microstrucure, the semantic aspect could be found in setting, detail, intention, presupposition, and normalization.
\end{abstract}

Keywords: Critical Discourse Analysis (CDA), Van Dijk's design, text

\section{INTRODUCTION}

According to Van Dijk (2001), Critical Discourse Analysis (CDA) is a type of discourse analytical research that principally studies the way social power abuse, dominance, and inequality are enacted, reproduced, and resisted by text and talk in the social and political context. CDA is mainly focused on the relationship between language and power. The clear position is then taken in CDA to understand, depict, and eventually oppose social disparity (Saadabad \& Kasmani, 2014, p. 61; Deocampo, 2015, p. 38). Meanwhile, Brown and Yule define discourse analysis as an investigation of language in use and which is fundamentally interested in the extra-sentential levels, is all in all regarded as a recent field of linguistics (cited by AlHaq \& Al-Sleibi, 2015, p. 317).

In CDA, language is considered a representative which shapes subject, theme, or certain ideology. The way CDA sees the language as the key factor utilized in looking at power imbalance occurring among people. The essential characteristics of critical analysis explained by Van Djik (1995) and Fairclough, et al., (1997, p. 357) are action, context, history, authority and ideology.

Several previous related studies of CDA on a number of world leaders' presidential speeches have been conducted. To make an example, Wang (2010, p. 254) analyzed Barrack Obama's speech and revealed that the speech language served both the ideology and power. Meanwhile, Recep Tayyip Erdogan's speech was studied by Bayram (2010, p. 23) who examined within the context of ideology, culture and language background. Recently, Rachman \& Yunianti, 2017, p. 8) revealed how Donald Trump delivered his ideology to reach the power in which he is able to control people and wins their heart. 
In particular with the speeches delivered by Indonesian presidents, some previous studies have also been conducted. For instance, Soekarno's speech was studied by Kone (2016, p. 153-157), SBY's speech by Priatmoko \& Cahyono (2013, p. 2-14), and Jokowi's speech by Saputro (2015, p. 1-120).

Why Jokowi? Joko Widodo, more well-known as Jokowi, is the seventh president of Indonesia. As the leader of a country, Jokowi certainly has a very influential role in bringing people's ideas. Unlike with several presidents before, Jokowi has been widely known as a modest leader. When he was the governor of Jakarta, he was always keen to have a visit so-called blusukan to community to directly see the condition and the problems occurring in the place. Surprisingly, before he was officially declared as president, due to his unique and modesty, a prominent international magazine TIME chose him to be its cover. The Time said "Jokowi is the force of Indonesia". His being recognized in this magazine obviously showed us that Jokowi is not only well-known in Indonesia, but also in other countries.

In the regard with the text choice, this speech is Jokowi's first presidency speech in front of international audience. Even though simple, according to some political observers like Effendi Ghazali, this speech was interesting for it directly touched the main problem without being wordy (Kompas, 2014). Moreover, this thirteenminute speech was regarded able to meet the needs of APEC participants because Jokowi delivered matters relevant with the forum.

This article was aimed at analyzing the text of Jokowi' speech based on Van Dijk's design in which the unit elements of the analysis are divided into three parts: macro-structure, supra-structure and micro- structure.

\section{METHODOLOGY}

The method of this research was descriptive qualitative with the approach of critical discourse analysis. The use of the method was to systematically, factually and accurately obtain a brief picture of facts and characters of the research object. Then, to analyze Jokowi's speech, the model developed by Teun A. Van Dijk, consisting of macrostructure, suprastructure and microstructure, was implemented. The primary data was the the transcript of speech delivered by President of Indonesia Joko Widodo at APEC CEO Summit Asia Pacific in Beijing, China on November 10, 2014. The speech was retrieved from the website https://www.rappler.com. The full text of the speech can be seen as follows:

Excellencies, distinguished guests, ladies and gentlemen, and CEOs, good morning.

First, on behalf of the Indonesian Government and the people of Indonesia, I would like to thank you for coming to my presentation. Today, I am happy, I am very happy, to be with you, because you know I was a businessman years ago. So, this morning, I am very happy because we can talk about business, about investment with all of you.

The picture shows you our map of Indonesia. We have a population of 240 million and the distance is like from London in UK to Istanbul in Turkey. And imagine, we have 17,000 islands. 17,000 islands.

Our national budget for 2015 is $\$ 167$ billion and for fuel subsidy is $\$ 27$ billion. It's huge. So we want to channel our fuel subsidy from consumption to the productive activities. From consumptive activities to productive activities. We want to channel our fuel subsidy to the farm for seeds, for fertilizers, and also for irrigation. And we want to build dams - 25 dams in 5 years from our fuel subsidy to maintain the water supply to the farming area. 
Some subsidy we want to channel to the fishermen, to give them boat engines, to give them refrigerators. We want to increase the income of the fishermen. Some fuel subsidy we want to give to micro and small enterprises in the villages. We want to help them raise their working capital. And some subsidy we want to channel to the health program, the education program. And some subsidy we want to channel to infrastructure.

In 5 years we want to build 24 seaports and deep seaports. As you know, we have 17,000 islands, so we need seaports and we need deep seaports. And this is your opportunity: 24 seaports and deep seaports.

The picture shows our Jakarta Port, Tanjung Priok port. In 2009, the capacity is 3.6 million TEUs a year, and our plan in 2017 is around 15 million TEUs a year. This is the potential ports in Indonesia. This is your opportunity. We want to build in Sumatera island, in Kalimantan island, in Java island, in Sulawesi island, in Maluku island, also in Papua island.

And we plan to build our railway track, railway network. Now we have already in Java and we want to build in Sumatera island, in Kalimantan island, in Sulawesi island and also in Papua island. This is your opportunity.

Nowwetalkaboutmasstransportation. We want to build our mass transportation in 6 big cities in Indonesia. We have started in Jakarta last year, and we want to build in Medan, in Makassar, in Semarang, in Bandung, in Surabaya. So, this is also your opportunity, because you know our national budget is limited.

Now we talk about our maritime agenda. We want to build sea toll. What is sea toll? Sea toll is maritime transportation system to make our transportation cost lower, to make our transportation cost more efficient. We want to build from the west to the east. We hope not only the vessels can enter our sea toll but also mother vessels can enter the sea toll. So, the price, the cost of the transportation is more efficient.

For example, the price of the cement, one sack cement, in Java island is $\$ 6$ per sack cement. But in Papua island the price is $\$ 150$ per sack cement. Imagine, 25 times. So we hope with our sea toll the price in our islands is the same.

Electricity. We need power plants. We need around 35,000 megavolts to build our industries, to build our projects, to build our industrial zones, our manufacturing zones. So, we need power plants. This is also your opportunity to invest in this project. Because we need our power plants for manufacturing, for industrial zones.

Many investors, a lot of investors, when they come to me, most of them they always complain about land acquisition. I will push my ministers, my governors, my mayors, to help clear this problem. I have experience with land acquisition when I was a governor. We have a project, the Jakarta Outer Ring Road, started 15 years ago but was stopped 8 years ago, because we have a problem here: 1.5 kilometers unfinished because there is 143 families who do not accept with the compensation price. So last year I invite them. I go to them then I invite them to lunch and dinner. Four times. Ah, this is me. I invite them and then we talk about the problem. Four times. Four times meeting. And the problem is cleared.

And now the toll road has been used (starting) 7 month ago.

Now we talk business permit. We have national one-stop service office that can help you, that will serve you, that will facilitate you, that will give you your business permit. For example, principle business permit needs 3 days to process.

Finally, again on behalf of the Indonesian government and the people of Indonesia, I would like to thank you for your listening (to) my presentation. We are 
waiting for you to come to Indonesia. We are waiting for you to invest in Indonesia. morning.

Thank you. Thank you. Good

\section{FINDINGS AND DISCUSSION}

\section{Text Analysis}

Fairclough, cited by Gowhary, et al. (2015,p.132), assertsthat therearethreestages of doing CDA: text analysis (description), processing analysis (interpretation), and social analysis (explanation). However, this paper will discuss mainly on text analysis designed by Van Dijk. The unit elements on the text analysis are divided into three parts, namely macro structure in which the text is analyzed thematically/topically. The second part is supra structure in which parts and order of the text are schemed in whole. Then the third part is called micro structure consisting of semantic, syntactic, stylistic, and rhetoric analysis.

\section{Macrostructure: Thematic}

As previously mentioned, thematic analysis is analyzing the theme or the topic of a discourse. It is a general picture of a text. Van Dijk calls it as global coherence, that is the elements of the text are sequenced and referred to one general idea. Those elements are supporting each other to describe the general topic. Wang \& Guo (2014, p.460) define coherence as a dynamic process and can be achieved by the cooperation made by the discourse producer and receiver based on their mutual understanding.

The theme of this speech is more likely to be economic. It can be clearly seen from almost all paragraphs in the speech. The several ideas construct a single general topic, economics. It is shown by his mentioning about many thing related to Indonesian economics. To make it clearer, here are some paragraphs representing the general theme of Jokowi's speech.

1) In speech opening he said "Today, I am happy, I am very happy, to be with you, because you know I was a businessman years ago. So, this morning, I am very happy because we can talk about business, about investment with all of you."

Text (1) shows us that Jokowi's speech is about economics in the field of business and investment.

2) In paragraph 4, Jokowi said, "Our national budget for 2015 is $\$ 167$ billion and for fuel subsidy is $\$ 27$ billion. It's huge. So we want to channel our fuel subsidy from consumption to the productive activities. From consumptive activities to productive activities. We want to channel our fuel subsidy to the farm for seeds, for fertilizers, and also for irrigation. And we want to build dams - 25 dams in 5 years from our fuel subsidy to maintain the water supply to the farming area."

His mentioning national budget in text (2) tells the audience the economic condition of Indonesia. Moreover, in this paragraph, Jokowi also obviously indicated the importance of economic aspect to support other big aspects like farming.

3) In the paragraph 13, Jokowi talked about the need of bigger capacity of electricity which is going to support industry.

Electricity. We need power plants. We need around 35,000 megavolts to build our industries, to build our projects, to build our industrial zones, our manufacturing zones. So, we need power plants. This is also your opportunity to invest in this project. Because we need our power plants for manufacturing, for industrial zones.

Saying the field of manufacturing and industry means that this paragraph is also still in line with the previous paragraph, about business and investment. From the several paragraphs, it can clearly understood that the topic of the sentence is about economy in term of business and investment. 


\section{Suprastructure: Schematic}

According to Van Dijk in Kuntoro (2008), Supra structure is defined as frame of a text, such as opening, content, closing and conclusion. Schematic, as supra structure of the discourse analysis, observes how elements and scheme of the news is ordered in a whole form. Meanwhile, Fairclough (2003, p. 72) call this as generic structure of text "the overall structure or organization of a text." Generic structure also plays a role in implementing the power. Jokowi's speech is in general divided into three main elements, namely opening, content and closing.

\begin{tabular}{|c|c|c|c|}
\hline Part & Paragraph & & Description \\
\hline Opening & $\begin{array}{l}\text { Paragraph } \\
1-5\end{array}$ & 3. & $\begin{array}{l}\text { Opening } \\
\text { remarks } \\
\text { Saying thanks, } \\
\text { expressing } \\
\text { feeling. } \\
\text { Describing the } \\
\text { population and } \\
\text { geographical } \\
\text { condition of } \\
\text { Indonesia. } \\
\text { Describing } \\
\text { national budget, } \\
\text { and plan of } \\
\text { channeling fuel } \\
\text { subsidy from } \\
\text { consumption to } \\
\text { the productive } \\
\text { activities. } \\
\text { Detailing } \\
\text { some areas to } \\
\text { which the fuel } \\
\text { subsidy will be } \\
\text { channeled. }\end{array}$ \\
\hline
\end{tabular}

$\begin{array}{ll}\text { Content } & \text { Paragraph } \\ & 6-14\end{array}$

6. Plan of building 24 seaports and deep seaports

7. Talking specifically about a port in Jakarta and invitation of infestation.

8. Plan of building railway.

9. Talking about mass transportation.

10. Talking about maritime agenda.

11. Exemplifying a significant difference of price of goods in different island as an impact of inefficient transportation cost.

12. Talking about the need of bigger capacity of electricity.

13. Telling the plan of repairing the clearance of the land acquisition.

14. Talking about business permit.

$\begin{array}{llr}\text { Closing Paragraph } & \text { 15. } \begin{array}{l}\text { Inviting } \\ \text { audience to } \\ \text { invest and } \\ \end{array} & \text { saying thanks. } \\ & & \end{array}$

Table I: Text Structure of Jokowi’s Speech

\section{Microstructure: Semantic}

Microstructure refers to localmeaning of a text which can be understood from the 
word choice, sentence and language style used in a text. Semantics is the meaning emphasized through the text. For instance, by giving details on one side or explicitly stating one side and reduce the other side. Esfehani (2013, p. 15) maintains that semantic or conceptual representation of a text is constructed in the writer's memory, so the text is understood and represented in the reader's mind. By semantics, the text is analyzed from its setting, detail, intention, presupposition, and nominalization.

\section{Setting}

Setting has an urgent role in a text. It can reveal the writer's goal and intention. Madkur (2014, p. 3) highlights that the speakers usually have the expectation that their communicative invitations will be organized by the listener. Setting is described as an aspect which is used to portray the background of an event. In addition, it can give us the indication where the text is directed. Setting can be verifying idea to confirm something in the text.

In the context of Jokowi's speech, the setting can be vividly seen from his speech opening by saying:

Today, I am happy, I am very happy, to be with you, because you know I was a businessman years ago. So, this morning, I am very happy because we can talk about business, about investment with all of you.

From the above statement "I am very happy because we can talk about business, about investment with all of you", it can be seen that the setting of the speech is business in term of investment. This is of course matched with what is expected by that event, APEC which is concerned with economic development.

\section{Detail}

Detail is employed as the writer's strategy to stress some parts he wants to tell more. Through the element of detail, the writer's behavior can be delivered implicitly. It is also stated by Eriyanto (2009) that detail is added to strengthen meaning of a text. Detail is intentional emphasis to create certain image toward audience, either positive or negative. In Jokowi's speech, one of detail can be seen from paragraph 13 as follows:

Many investors, a lot of investors, when they come to me, most of them they always complain about land acquisition. I will push my ministers, my governors, my mayors, to help clear this problem. I have experience with land acquisition when I was a governor.

From this saying, Jokowi tried to have the audience know one of problems in investing in Indonesia, namely complicated land acquisition. Then the second sentence I will push my ministers, my governors, my mayors, to help clear this problemand the third sentence I have experience with land acquisition when I was a governor are used to create good image of Jokowi that he, with his experience and instruction to his inferior persons, can solve this problem.

In its explanation, when information is positive or needs to be stressed, the intention is served clearly and with the distinct words. On the contrary, if the information is negative or the writer wants to state it in other version, the writer can deliver it euphemistically and sinuously.

Talking about the intention, Jokowi explicitly intended to promote several areas in which people from outside of Indonesia can take a part in investment. It is shown by his five-time mentioning about inviting the audience to invest. Among others are the following:

1) In paragraph 1, "I am very happy because we can talk about business, about investment with all of you." 
2) "This is also your opportunity to invest in this project."

3) "Many investors, a lot of investors, when they come to me, most of them they always complain about land acquisition."

4) Eventually, he ended his speech by saying "We are waiting for you to invest in Indonesia."

Those show that Jokowi strongly states his intention to persuade the audience coming from various countries to distribute their infestation in Indonesia. No other reason Jokowi has but making the development of those areas faster so that the economic activities can run better.

Of the explicit statements of investment, in paragraph 6, there are also clear, although not stating the word investment, statements that refer to the same intention. Jokowi used five-time mentioning word "opportunity". They are:

1) “And this is your opportunity: 24 seaports and deep seaports." (paragraph 6)

2) "The picture shows our Jakarta Port, TanjungPriok port. In 2009, the capacity is 3.6 million TEUs a year, and our plan in 2017 is around 15 million TEUs a year. This is the potential ports in Indonesia. This is your opportunity. We want to build in Sumatera island, in Kalimantan island, in Java island, in Sulawesi island, in Maluku island, also in Papua island." (paragraph 7)

3) "And we plan to build our railway track, railway network. Now we have already in Java. We want to build in Sumatra Island, in Kalimantan Island, in Sulawesi Island, and also in Papua Island. This is your opportunity...”(paragraph 8)

4) "So, this is also your opportunity, because you know our national budget is limited."(paragraph 9)

5) So we need power plant. This is also your opportunity to invest in this project because we need our power plant for manufacturing and industrial zone. (paragraph 12)

This was like Marthin Luther King did in his very famous speech "I have adream."He specially repeated the same phrases for several times so that those words memorable for the audience's ears. Similarly, Jokowi repeated the sentence "this is your opportunity"to catch the audience attention especially the CEOs.

Furthermore, the clause "you know I was a businessman" in the speech opening shows that Jokowi attempted to ensure the audience that he is an eligible and right person to talk about business since he was also known as a businessman. Before he was the mayor of Surakarta in 2005, he had worked as a property and furniture businessman. This is god to make same perception among Jokowi and audience about what is going to talk, business and investment.

\section{Presupposition}

This is a statement which is used to support or to strengthen a text. Presupposition is identified through trusted premises. Based on this strengthening, the writer can describe information reliably. Presupposition is common ground between the speaker and the listener. The speaker presupposes that the listener understands what is presupposed.

In Jokowi's speech, there were some presuppositions made by Jokowi. For example, in paragraph 14 :

Now we talk business permit. We have national one-stop service office that can help you, that will serve you, that will facilitate you, that will give you your business permit. For example, principle business permit needs 3 days to process.

The sentence "Now we talk business permit." indicates that Jokowi presupposed that his audience has already known about 
business permit and especially business permit in Indonesia.

\section{Syntactic}

Syntactic is connecting sentences coherently to convey a fact. Eriyanto divides the syntactic into the following elements:

\section{Sentence Type}

Sentence type focuses on the position of subject in a sentence. This is in connection with the assumption that meaning formation is influenced by type or form of sentence. In Jokowi's speech, almost all sentences are in active form in which the subject is positioned in the beginning of sentence. For example:

\section{Paragraph 4}

....We want to increase the income of the fishermen. Some fuel subsidy we want to give to micro and small enterprises in the villages. We want to help them raise their working capital. And some subsidy we want to channel to the health program, the education program. And some subsidy we want to channel to infrastructure.

\section{Paragraph 13}

Many investors, a lot of investors, when they come to me, most of them they always complain about land acquisition. I will push my ministers, my governors, my mayors, to help clear this problem. I have experience with land acquisition when I was a governor. We have a project, the Jakarta Outer Ring Road, started 15 years ago but was stopped 8 years ago, because we have a problem here: 1.5 kilometers unfinished because there is 143 families who do not accept with the compensation price. So last year I invite them. I go to them then I invite them to lunch and dinner. Four times. Ah, this is me. I invite them and then we talk about the problem.
In the two paragraphs, like other paragraphs, Jokowi used active sentence. This can be understood as his way to show his seriousness in playing a vital role as an active person in organizing numerous big programs.

\section{Pronoun}

Pronoun is used to demonstrate somebody's position in a discourse through imaginative languages. Byutilizing pronoun, the writer's attitude and perspective can be expressed. The use of different pronoun, in other words, will give different interpretation related to the perspective which will be delivered.

Regarding with the use of pronoun, Jokowi used pronoun "I" for 13 times, 5 possessive adjective "my" and 2 object pronoun "me". Significantly different, the use of subject pronoun "we" occurred 40 times, possessive adjective pronoun "our" occurred 14 times. Pronoun "I" is used by Jokowi to act as the president, show that he does something by himself, or to give his own, experience, impression or opinion. For example:

\section{Paragraph 1:}

$I$ would like to thank you for coming to $\boldsymbol{m y}$ presentation. Today, $\boldsymbol{I}$ am happy, $\boldsymbol{I}$ am very happy.

This utterance was delivered by Jokowi to show his feeling, thankful and happy, to talk in the summit.

\section{Paragraph 13:}

So last year $\boldsymbol{I}$ invite them. $\boldsymbol{I}$ go to them then $\boldsymbol{I}$ invite them to lunch and dinner. Four times. Ah, this is me. $\boldsymbol{I}$ invite them and then we talk about the problem. Four times. Four times meeting. And the problem is cleared. The above sentence tells the audience about Jokowi's personal experience in solving a problem. The pronoun "I" brings the audience to know 
that Jokowi himself has a good track record in managing people's displacing.

Meanwhile, the use of "we" refers to the use of subject related to Indonesian people. Meaning to say, when using "we", Jokowi involves people as a whole and to show his empathy and togetherness with people in possessing or conducting something. To illustrate this point, it can be seen from some paragraphs.

\section{Paragraph 4:}

Our national budget for 2015 is $\$ 167$ billion and for fuel subsidy is $\$ 27$ billion. It's huge. So we want to channel our fuel subsidy from consumption to the productive activities. From consumptive activities to productive activities. We want to channel our fuel subsidy to the farm for seeds, for fertilizers, and also for irrigation. And we want to build dams - 25 dams in 5 years from our fuel subsidy to maintain the water supply to the farming area.

The pronoun "our" and "we" in this paragraph mean that it is not merely Jokowi who own budget but all Indonesian citizens. Meaning to say, it is not Jokowi's individual work, but Jokowi and the government.

Due to higher frequency of "we" than "I", it is indicated that Jokowi tried to not be individual and involve Indonesian people in making image in front of international audience.

\section{Coherence}

Coherence is connecting two different languages in order to make a connected and coherent sentence. This is a very important part both in spoken and writen language (Madkur, 2013,p. 65). In this case, coherence can be indicated from the availability of conjunction. Several conjunctions such as and, result, for, but, or and so forth can give different perception.

In term of coherence, Jokowi seems inconsistent because he made good coherence in some paragraphs but lack in the others. To illustrate, the speech is actually quite lack of conjunction especially to connect one paragraph to another paragraph. It can be seen, for example, from the shift from paragraph 11 to 12 as follows:

Paragraph 11

For example, the price of the cement, one sack cement, in Java island is \$6 per sack cement. But in Papua island the price is $\$ 150$ per sack cement. Imagine, 25 times. So we hope with our sea toll the price in our islands is the same.

\section{Paragraph 12}

Electricity. We need power plants. We need around 35,000 megavolts to build our industries, to build our projects, to build our industrial zones, our manufacturing zones....

When moving from the topic of high cost of transportation to the topic of electricity, Jokowi didn't use any conjunction or transition. As a consequence, the two paragraphs less coherent. It will be better if Jokowi used such conjunctions as The next is.....,Thirdly..... and so forth.

Also, in paragraph 13, Jokowi should have used conjunction for expressing the meaning of result:

Many investors, a lot of investors, when they come to me, most of them they always complain about land acquisition. I will push my ministers, my governors, my mayors, to help clear this problem.

It would be better if there is a 
conjunction like therefore, as a result, hence and so forth to make the two sentences more connected. Because the second sentence is the result or response for the first sentence.

However, Jokowi also used some conjunctions illustrated in several paragraphs:

\section{Paragraph 12:}

.......We need around 35,000 megavolts to build our industries, to build our projects, to build our industrial zones, our manufacturing zones. So, we need power plants. This is also your opportunity to invest in this project. Because we need our power plants for manufacturing, for industrial zones.

In the paragraph, the conjunction so is very useful to convey that to build industries, to build projects, to build industrial zones, and manufacturing zones, Indonesia needs power plants.

What seems redundancy is the last sentence of the paragraph. It is in fact already conveyed in the previous sentence.

The other conjunction used is and to show the equal position of first and second sentence; it is like in paragraph 2:

......We have a population of 240 million and the distance is like from London in UK to Istanbul in Turkey....

To express contrast meaning, Jokowi used conjunction but like in paragraph 11:

For example, the price of the cement, one sack cement, in Java island is $\$ 6$ per sack cement. But in Papua island the price is $\$ 150$ per sack cement.

\section{Differentiating coherence}

This is in relation with the statement how two facts or events can be differentiated.
Distinguishing coherence uses conjunction to arouse contrast meaning briefly. For example, the conjunction than or compared to makes two or more events contradictive.

In term of differentiating, Jokowi used but to inform the difference of two places. It is in paragraph 11 that Jokowi told the audience the significant difference the price of cement between Java island and Papua island. It is:

For example, the price of the cement, one sack cement, in Java island is $\$ 6$ per sack cement. But in Papua island the price is $\$ 150$ per sack cement.

\section{Stylistic}

Stylistic places language as an essential aspect. It is directed to explore language in a specific way or to decipher the creative use of language. What is included in stylistic is as follows:

\section{Lexicon}

Unlike many orators or public speakers, Jokowi was able to deliver his presentation by using simple English. It could be understood by all people. Many people complimented his speech for its "simple and plain English". It is in line with Albert Einstein's saying "if you cannot explain something in simple language, it means that you have not yet understood what you are explaining"

\section{Rhetoric}

Rhetoric is one of ways to dig the writer's ideology in expressing his thoughts into a text. In writing text, the use of accessories such as underline, bold, letter font, adverb, picture, analogies, or other accessories is to stress purpose and thoughts of the writer. Those accessories are:

\section{Graphic}

It is a tool to show particular parts which will be emphasized. For instance, by using bolded letter, italic, underline, 
different letter font, photo form, picture or table. Graphic element gives cognitive effect in a discourse to control attention interest.

It has been one Jokowi's habit to always use graphics, pictures or charts while delivering speech. Because of these media, even though his English pronunciation is not really fluent, Jokowi could attract the audience's attention well. In this speech, Jokowi always attach slide for each point he spoke. For example he showed the map of Indonesia while talking paragraph 2:

The picture shows you our map of Indonesia. We have a population of 240 million and the distance is like from London in UK to Istanbul in Turkey. And imagine, we have 17,000 islands. 17,000 islands.

\section{Metaphor}

Metaphor is an analogy delivered by the writer to give correction toward the information already conveyed. In practical, metaphor can be pictured through beliefs, everyday expressions, analogies, adverb, and forefather's advice or even from verses of Qur'an.

In Jokowi's case, he did not use metaphor. He preferred to use data to empower the information he delivered. For example in paragraph 6:

The picture shows our Jakarta Port, Tanjung Priok port. In 2009, the capacity is 3.6 million TEUs a year, and our plan in 2017 is around 15 million TEUs a year. This is the potential ports in Indonesia. This is your opportunity.

\section{Denial}

It is stated by Eriyanto (2009: 47) that denial is an element by which public can break down the writer's attitude and expression delivered mysteriously. The hidden things describe the writer's agreement on a certain statement; whereas, he actually wants something else. Denial is commonly done in the end of discourse. In a text, denial can be expressed by but. An example of denial in Jokowi's speech can be seen from paragraph 13:

..."We have a project, the Jakarta Outer Ring Road, started 15 years ago but was stopped 8 years ago, because we have a problem here: 1.5 kilometers unfinished because there is 143 families who do not accept with the compensation price...."

\section{CONCLUSION}

This first presidency speech of Jokowi has attracted big impression of both like and dislike. From the perspective of critical discourse analysis, it is seen that he was successful in stating theme, creating scheme, expressing semantic, and rhetoric. However, several sentences in the presidential speech were not really coherent but still could be understood since he attached many pictures and graphs.

What becomes very clear to make Jokowi distinctive from many other international public speakers is that he employed simple and plain language. Furthermore, he kept himself natural with his style and confident with his English pronunciation which is clearly influenced by his Javanese accent. Those which have been done by Jokowi can be a very good lesson for us when speaking in front of audience.

\section{REFERENCES}

Al-Haq, F. A.-A., \& Al-Sleibi, N. M. (2015). A Critical Discourse Analysis of Three Speeches of King Abdullah II. US-China Foreign Language, 13(5), 317-332. https://doi.org/10.17265/15398080/2015.05.001

Bayram, F. (2010). Ideology and Political Discourse: A Critical Discourse Analysis of Erdogan's Political Speech. ARECLS, 7(1), 18. 
Deocampo, M. F. (2015). The New English Teacher. The New English Teacher, $9(1), 38-62$.

Eriyanto. (2009). Analisis Wacana: Pengantar Analisis Teks Media. Yogyakarta: Lkis.

Esfehani, L. S. (2013). From Macro and Microstructures to an Innovation: The Macrofiction Structure. International Journal of English Language and Linguistics Research, 1(2), 18.

Fairclough, N., Mulderrig, J., \& Wodak, R. (1997). Critical Discourse Analysis. In Discourse Studies: A Multidisciplinary Introduction ( $\mathrm{p}$. 357). London: Sage Publication.

Gowhary, H., Rahimi, F., Azizifar, A., \& Jamalinesari, A. (2015). A Critical Discourse Analysis of the Electoral Talks of Iranian Presidential Candidates in 2013. Procedia Social and Behavioral Sciences, 192, 132-141. https://doi.org/10.1016/j. sbspro.2015.06.020

Kone, A. M. (2016). Metaphor in Ir. Soekarno'sSpeech. Researchers World : Journal of Arts, Science and Commerce, 7(4), 153-157. https:// doi.org/10.18843/rwjasc/v7i4(1)/18

Madkur, A. (2013). Grammatical Analysis on the Abstract of Scientific Writing. Pedagogy: Journal of English Language Teaching, 1(1), 52-67.

Madkur, A. (2014). Pragmatics in EFL Instruction: Speech Acts in English Speaking Class (Vol. 1, p. 7). Presented at the Siliwangi International English Conference (SIEC), Tasikmalaya: Siliwangi University.

Priatmoko, F. X. N. A., \& Cahyono, S. P. (2013). Critical Discourse Analysis of Susilo Bambang Yudhoyono's Speech. Dian Nuswantoro University Semarang, 14.

Rachman,A., \& Yunianti, S. (2017). Critical Discourse Analysis in Donald Trump Presidential Campaign to Win American's Heart. TELL Journal, 5(2), 8-17.

Saadabad, M. H., \& Kasmani, M. B. (2014). A Critical Discourse Analysis of Summit Series: There presentation of Social Actors. Asian Journal of Social Sciences \& Humanities, 3(2), 61-71.

Saputro, E. P. N. (2015). The Analysis of Illocutionary Acts of Jokowi's Speeches (Master Thesis). Sanata Dharma University, Yogyakarta.

Van Dick, T. A. (1995). Discourse Analysis as Ideology Analysis. In Language and Peace (pp. 17-33). Aldershot: Darmouth Publishing.

Van Dick, T. A. (2001). Multidisciplinary CDA: A Plea for Diversity. In Methods of Criticaal Discourse Analysis. London: Sage Publication. Retrieved from http://www. discourse.org

Wang, J. (2010). A Critical Discourse Analysis of Barack Obama's Speeches. Journal of Language Teaching and Research, 1(3), 254-261. https://doi.org/10.4304/ jltr.1.3.254-261

Wang, Y., \& Guo, M. (2014). A Short Analysis of Discourse Coherence. Journal of Language Teaching and Research, 5(2), 460-465. https:// doi.org/10.4304/j1tr.5.2.460-465 